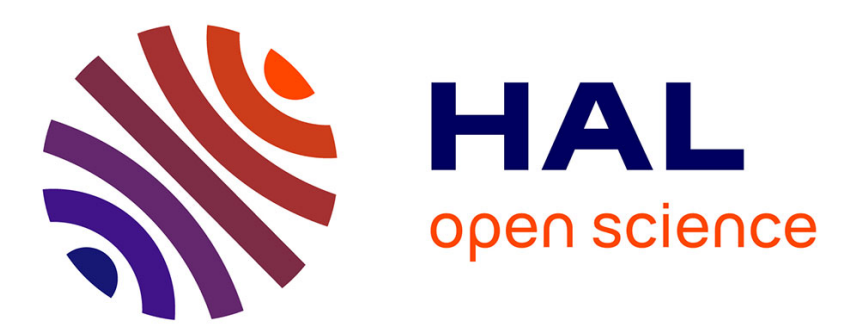

\title{
The ammonites of the Les Ferres Aptian Basin (Lower Cretaceous, Southeast of France): the genus Toxoceratoides (Ancyloceratina, Helicancylidae)
}

\author{
Stéphane Bersac, Didier Bert
}

\section{- To cite this version:}

Stéphane Bersac, Didier Bert. The ammonites of the Les Ferres Aptian Basin (Lower Cretaceous, Southeast of France): the genus Toxoceratoides (Ancyloceratina, Helicancylidae). Cretaceous Research, 2021, 118, pp.104661. 10.1016/j.cretres.2020.104661 . insu-02966450

HAL Id: insu-02966450

https://hal-insu.archives-ouvertes.fr/insu-02966450

Submitted on 14 Oct 2020

HAL is a multi-disciplinary open access archive for the deposit and dissemination of scientific research documents, whether they are published or not. The documents may come from teaching and research institutions in France or abroad, or from public or private research centers.
L'archive ouverte pluridisciplinaire HAL, est destinée au dépôt et à la diffusion de documents scientifiques de niveau recherche, publiés ou non, émanant des établissements d'enseignement et de recherche français ou étrangers, des laboratoires publics ou privés. 


\section{Journal Pre-proof}

The ammonites of the Les Ferres Aptian Basin (Lower Cretaceous, Southeast of France): the genus Toxoceratoides (Ancyloceratina, Helicancylidae)

Stéphane Bersac, Didier Bert

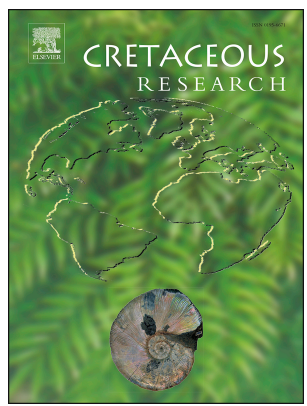

PII:

S0195-6671(20)30347-5

DOI: https://doi.org/10.1016/j.cretres.2020.104661

Reference: $\quad$ YCRES 104661

To appear in: Cretaceous Research

Received Date: 13 May 2020

Revised Date: 11 August 2020

Accepted Date: 26 September 2020

Please cite this article as: Bersac, S., Bert, D., The ammonites of the Les Ferres Aptian Basin (Lower Cretaceous, Southeast of France): the genus Toxoceratoides (Ancyloceratina, Helicancylidae), Cretaceous Research, https://doi.org/10.1016/j.cretres.2020.104661.

This is a PDF file of an article that has undergone enhancements after acceptance, such as the addition of a cover page and metadata, and formatting for readability, but it is not yet the definitive version of record. This version will undergo additional copyediting, typesetting and review before it is published in its final form, but we are providing this version to give early visibility of the article. Please note that, during the production process, errors may be discovered which could affect the content, and all legal disclaimers that apply to the journal pertain.

() 2020 Elsevier Ltd. All rights reserved. 
The ammonites of the Les Ferres Aptian Basin (Lower Cretaceous, Southeast of France): the genus Toxoceratoides (Ancyloceratina,

Helicancylidae)

4

$7^{\text {a }}$ Laboratoire du Groupe de recherche en paléobiologie et biostratigraphie des

8 Ammonites (GPA), Bois-Mésanges, quartier Saint-Joseph, F-04170 La Mure-

9 Argens, France

$10^{\mathrm{b}}$ Réserve naturelle nationale géologique de Haute-Provence, service

11 Environnement, Conseil départemental des Alpes de Haute-Provence, 13, rue du

12 Docteur-Romieu, CS 70216, F-04995 Digne-Les-Bains cedex 9, France

$13{ }^{\mathrm{c}}$ Laboratoire Géosciences, UMR-CNRS 6118, université de Rennes-1, campus

14 Beaulieu, bâtiment 15, F-35042 Rennes cedex, France

15 * Corresponding author: geosteber@yahoo.fr (S. Bersac)

17 Abstract: 
18 Toxoceratoides (Ancyloceratina, Helicancylidae) is a lower Aptian (Lower

19 Cretaceous) small heteromorph ammonoid mainly known by small samples of 20 fragmentary specimens. In the present work, we study a sample of 145 21 specimens of this genus from the Deshayesites forbesi, Deshayesites deshayesi 22 and Dufrenoyia furcata zones (lower Aptian) of the vicinity of the village of Les 23 Ferres (southeastern France). The taxa recognized (in stratigraphic order) are: 24 Toxoceratoides sp., Toxoceratoides royerianus (d'Orbigny, 1842) and 25 Toxoceratoides rochi Casey, 1961. Their ontogenetic sequence is described; the 26 intraspecific variability of Toxoceratoides rochi is considerable and it concerns 27 adult size, coiling, duration of the ontogenetic stages and ornamentation. No 28 sexual dimorphism is recognized. The main evolutionary pattern of the genus 29 consists in the replacement of primitive ribs (here named 'royerianus ribs') by 30 derived ribs ('rochi ribs') on the flexus and retroversum. The genus 31 Toxoceratoides could be used as a biostratigraphic tool.

33 Key words: heteromorph ammonite; evolution; ontogeny; intraspecific 34 variability; heterochronic variation. 
38 The Les Ferres Aptian Basin (LFAB) is a small subsident basin nowadays 39 located in the vicinity of the village of Les Ferres, in the Esterron valley (Alpes40 Maritimes department, southeastern France, Bersac and Bert, 2019, Fig. 1). The 41 location of the outcrops studied and the lower Aptian litho- and biostratigraphy 42 of the LFAB have been previously described in Bersac and Bert (2019). The 43 LFAB is characterized by relatively thick lower Aptian deposits particularly rich 44 in macrofossils, especially ammonites (fossil cephalopods, Bersac and Bert, 45 2019). The age of these series extends from the Deshayesites forbesi Zone (in 46 the sense of Bersac et al., 2012) to the late Dufrenoyia furcata Zone (Dufrenoyia 47 dufrenoyi Subzone, Fig. 2). Its ammonite fauna is remarkable by the significant 48 proportion of heteromorphs of the families Ancyloceratidae Meek, 1876 and 49 Helicancylidae Hyatt, 1894 (=Acrioceratidae Vermeulen, 2004). In the LFAB, 50 the lower Aptian Helicancylidae are only represented by the genus 51 Toxoceratoides Spath, 1924 (Bersac and Bert, 2019), which is a small tripartite 52 shelled heteromorph genus (the shell of Toxoceratoides is composed of a 53 proversum, a flexus and a retroversum, Casey, 1961a; Aguirre-Urreta, 1986; 54 Avram, 2002; Bulot et al., 2018, Fig. 3). The aim of the present work is to 55 describe and figure the Toxoceratoides of the LFAB, based on a sample of 145 56 specimens from the $D$. forbesi-D. furcata zones interval. 
2. Material and method

59

60

2.1. Material

61

62 The litho- and biostratigraphic framework based on ammonites of the LFAB and

63 the sections from which the studied material originates are detailed in Bersac 64 and Bert (2019).

65 The material studied is composed of 145 specimens of Toxoceratoides from 6 66 sections of the LFAB. The specimens originate from: (1) the top of the 67 Hauterivian-Aptian limestones (Deshayesites forbesi Zone, 1 specimen), (2) the 68 Ammonitoceras Level of the Pont de la Cerise Member (Deshayesites 69 multicostatus Subzone of the Deshayesites deshayesi Zone, 1 specimen) and (3) 70 from the Les Graous Member (Deshayesites grandis Subzone of the D. 71 deshayesi Zone and D. furcata Zone, 143 specimens). They are represented by 72 marly-calcareous internal moulds, mostly deformed and fragmentary. The 73 studied material is curated by the Réserve naturelle nationale géologique de 74 Haute-Provence (RNNGHP, Digne-les-bains, France). The list of the studied 75 specimens is given in Supplementary Appendix. 
77 2.2. Method

78

79 The terminology used for describing the studied specimens and the criteria for

80 determining them are based on the works of Frau et al. (2017) and Bulot et al.

81 (2018). The variable $\mathrm{H}$ is the whorl height at the middle of the flexus (Fig. 3).

82 The ontogenetic sequence of the genus Toxoceratoides shows 3 successive 83 stages (Fig. 3):

84 - Stage $i$ (Bulot et al., 2018, p. 189) is adorned with uniform, simple and 85 atuberculate ribs or ribs bearing a single ventrolateral tubercle.

86 - Stage ii presents an 'alternation of (...) primary ribs and atuberculate 87 intercalatories' (Bulot et al., 2018, p. 189). The main ribs are tuberculate and 88 attenuated on the siphonal area. They are usually separated by one or more 89 atuberculate intercalary ribs but can be more rarely contiguous. The intercalary 90 ribs are generally not attenuated on the siphonal area. Stage $i i$ can be subdivided 91 in an early part named here 'stage iia' with bituberculate main ribs (lateral and

92 lateroventral tubercles, see Bulot et al., 2018, fig. 2R) and a late part named here 93 'stage $i i b$ ' with trituberculate main ribs (laterodorsal, lateral and lateroventral 94 tubercles). 
95 - Stage iii (Bulot et al., 2018, p. 189) is represented by various types of ribs: (1)

96 simple and atuberculate ribs named here 'rochi ribs' because they predominate

97 in the species Toxoceratoides rochi Casey, 1961 (Frau et al., 2017; Bulot et al.,

98 2018); (2) bifid ribs with a laterodorsal tubercle named here 'royerianus ribs'

99 because they predominate in the species Toxoceratoides royerianus (d'Orbigny,

100 1842) (Bulot et al., 2018); and (3) ribs with intermediate pattern (single with a

101 laterodorsal tubercle or atuberculate and bifid).

102 According to Bulot et al. (2018), the species Toxoceratoides royerianus evolves

103 toward the species Toxoceratoides rochi by the replacement of ontogenetic stage

104 iii's royerianus ribs by rochi ribs and by the change in shape of stage ii's

105 lateroventral tubercles. Thus, we consider the proportion of rochi ribs relative to

106 the total number of ribs of stage iii as a diagnostic character. We calculated such

107 proportion for the samples of each lithostratigrapic unit of the LFAB when 108 possible. We studied the distributions of $\mathrm{H}$ and of the proportion of rochi ribs 109 through frequency histograms and a Shapiro-Wilk normality test (Hammer and 110 Harper, 2006) for the only significantly larger subzonal sample (over 30 111 specimens), namely the sample from the D. furcata Subzone. They were 112 performed using the software PAST version 2.17c (Hammer et al., 2001, 113 http://folk.uio.no/ohammer/past/). 
114 Our taxonomic approach is based on a 'palaeobiologic' concept of the species 115 rather than a typologic concept (see discussions about these concepts in Bert, 116 2013; De Baets et al., 2015).

117 The database of the studied specimens is available in Supplementary Appendix.

119 3. Results

121 3.1. Descriptive paleontology

123 Order Ammonoidea Zittel, 1884

124 Suborder Ancyloceratina Wiedmann, 1966

125 Superfamily Ancyloceratoidea Gill, 1871

126 Family Helicancylidae Hyatt, 1894

128 Taxonomic considerations about the family-group name Helicancylidae. The 129 opinions of recent authors differ on the suprageneric classification of 130 Toxoceratoides: it could belong to the family Helicancylidae (Bert, 2009), to the 131 family Acrioceratidae (Vermeulen, 2004; Bulot in Vincent et al., 2010; Frau et 
132 al., 2017) or to the subfamily Helicancylinae of the family Ancyloceratidae (see

133 Casey, 1961a; Aguirre-Urreta, 1986; Kakabadze and Hoedemaeker, 2004;

134 Kakabadze in Klein et al., 2007, footnote p. 94). Here, we consider that the 135 genus Toxoceratoides belongs to a family distinct from the Ancyloceratidae on 136 the basis of the phylogenetic arguments developed by Bert (2009), and we use 137 the family-group name Helicancylidae for the following reasons:

138 - (1) following Bert (2009) and Bulot (in Vincent et al., 2010), we consider that 139 the family-groups Helicancylidae and Acrioceratidae share the same taxonomic 140 content and that both the two names designate the same family;

141 - (2) the family-group names Helicancylidae and Acrioceratidae meet all the 142 requirements of availability outlined in Articles 11 and 12 of the International 143 Code of Zoological Nomenclature (ICZN). Both are thus available in the sense 144 of the ICZN (see also Article 10.6);

145 - (3) according to the Principle of Priority (ICZN, Article 23), the name 146 Helicancylidae, Hyatt, 1894 has seniority on the name Acrioceratidae, 147 Vermeulen, 2004.

149 Toxoceratoides sp.

150 Fig. 4A 
1522019 Toxoceratoides sp. - Bersac and Bert, p. 155, fig. 12.

154 Material (see Supplementary Appendix). 1 specimen from the top of the 155 Hauterivian-Aptian limestones (Bed 400 of CLE section, Deshayesites forbesi 156 Zone).

158 Description. The specimen is a fragment of flexus and retroversum with $\mathrm{H}=9$ $159 \mathrm{~mm}$. Only one side of the specimen is preserved and its width cannot thus be 160 measured. Its ventral area is not preserved. The ornamentation is only composed 161 of royerianus ribs (slightly rursiradiate, thin, relatively dense and arising in pairs 162 from a laterodorsal tubercle). Apart the laterodorsal tubercle, these ribs do not 163 bear additional tubercle. The septal suture is not observable. The proportion of 164 rochi ribs is $0 \%$ (Table 1 ).

166 Discussion. This specimen is quoted in Bersac and Bert (2019, p. 157, fig. 12). It 167 originates from a bed (Bed 400 of CLE section) assigned to the lower part of the D. forbesi Zone. Its ornamentation corresponds to the ontogenetic stage iii. The 169 specimen shows primitive characteristics with a proportion of rochi ribs of $0 \%$ 
170 (ornamentation of its stage iii only represented by royerianus ribs). This

171 specimen may correspond to a primitive form of Toxoceratoides, just like those

172 figured by Avram (2002, pl. 1, figs. 9a, b, 12a-c, pl. 2, figs. 9, 12) and Delanoy

173 et al. (2008, pl. 11, fig. 4a, b). Our specimen differs from the lower Aptian small

174 heteromorph genus Volgoceratoides Mikhailova and Baraboshkin, 2002

175 (Mikhailova and Baraboshkin, 2002, p. 544) by its less distant ribs and its lower

176 position of the rib furcation point on the flexus and proversum. The imprecise

177 biostratigraphic position and the very fragmentary state of preservation of the

178 studied specimen prevent us to identify it at species level.

180 Biostratigraphic distribution. Deshayesites forbesi Zone of the LFAB.

182 Toxoceratoides royerianus (d'Orbigny, 1842)

183 Fig. 4B-G

1852019 Toxoceratoides aff. royerianus - Bersac and Bert, p. 155, 163, 164, figs. 5,

186 7, 10, 12, pl. 3, figs. 13-16.

187 For an extensive synonymy of this species, see Bulot et al. (2018). 
189 190 191 192 193 194

Material (see Supplementary Appendix). 1 specimen from Bed 405 of VAL section (D. multicostatus Subzone, D. deshayesi Zone) and 10 specimens from the Toxoceratoides Bed (D. grandis Subzone, D. deshayesi Zone) of GRS1, CLE and CHP sections. These 11 specimens were identified as Toxoceratoides aff. royerianus in Bersac and Bert (2019).

Description of the material of the D. multicostatus Subzone (D. deshayesi Zone). The specimen No. SBC.06061-00003/VAL066 (Fig. 4B) is the only Helicancylidae we collected in the D. multicostatus Subzone (D. deshayesi Zone) of the LFAB. It was identified as Toxoceratoides aff. royerianus in Bersac and Bert (2019, fig. 7). This specimen is a fragment of flexus and retroversum with $\mathrm{H}=13.9 \mathrm{~mm}$. Only one side of the specimen is preserved. The ornamentation of the flexus is represented by thick and straight main ribs bearing lateroventral and smaller lateral tubercles. The shape of the lateroventral tubercles is conical, slightly sagittally compressed. It is not possible to determine if these ribs bear or not a laterodorsal tubercle since the ornamentation is poorly preserved on the dorsal margin of the flexus. These main ribs are separated by one straight, thin and atuberculate intercalary rib. This ornamentation corresponds to the stage ii. On the retroversum, stage $i i$ is 
208 replaced by stage iii. Its ribs are simple and atuberculate (rochi ribs) or arise in 209 pairs from a laterodorsal tubercle (royerianus ribs). The peristome is not 210 preserved and the septal suture is not observable. The proportion of rochi ribs is $21142.85 \%$ for this specimen (Table 1).

213 Description of the material of the D. grandis Subzone (D. deshayesi Zone). The 21410 specimens of the $D$. grandis Subzone (D. deshayesi Zone) are all fragments 215 but it is nevertheless possible to follow their ontogeny from a specimen to 216 another. $\mathrm{H}$ has been measured only on 5 specimens; it varies from $7.2 \mathrm{~mm}$ to $21711.7 \mathrm{~mm}$ with a mean value of $10.04 \mathrm{~mm}$ (Table 1).

218 The ornamentation is visible from a whorl height of $1 \mathrm{~mm}$ and corresponds to 219 the stage iia (Fig. 4F). It is represented by simple, uniform, straight and 220 rectiradiate ribs attenuated on the siphonal area. These ribs bear a lateroventral 221 and a smaller lateral tubercle.

222 From a whorl height of $2.7 \mathrm{~mm}$ (Fig. 4F), ornamentation changes and 223 corresponds to stage $i i b$ : the ribs become slightly prorsiradiate and the siphonal 224 area becomes smooth to subsmooth. The main ribs bear a laterodorsal, a lateral 225 and a larger lateroventral tubercle. This latter can be conical or claviform. Two 226 main ribs are separated from each other by a single thin and atuberculate 227 intercalary rib (Figs 4F, G). 
228 At the beginning of the flexus, stage $i i b$ is abruptly replaced by stage $i i i$ (Bersac 229 and Bert, 2019, pl. 3, figs. 13, 14). Its ornamentation is represented by slightly 230 rursiradiate ribs that can be of royerianus, rochi or intermediate type. Most of 231 the specimens exhibit a mixture of each type of ribs (Fig. 4C1-D2, Bersac and 232 Bert, 2019, pl. 3, figs. 15, 16). One specimen (SBC.06061-00006/CHP038, Fig. 233 4E1, E2) exhibits some ribs bearing a discrete lateroventral tubercle. The 234 royerianus ribs seem to predominate on the flexus and the beginning of the 235 retroversum whereas the rochi ribs seem to be more frequent on the distal part of 236 the retroversum (Fig. 4C1, C2). On the proversum, the flexus and the 237 retroversum, the dorsal area is adorned with dense and thin ribs concave towards the peristome. No specimen has its peristome preserved. The septal suture is not observable. The proportion of rochi ribs has been measured on 4 specimens: it ranges from $30 \%$ to $61.53 \%$ and is $47.88 \%$ on average (Table 1 ).

Remarks on the biostratigraphic position of $\mathrm{T}$. royerianus in its type-stratum. T. royerianus was recently revised by Bulot et al. (2018) on the basis of topotype material from the Argiles à Plicatules (a lower Aptian formation of the Paris Basin, see Corroy, 1925; Amédro and Matrion, 2004; Bersac and Bert, 2015, 2018, 2020). Bulot et al (2018, fig. 3) argued that this formation ranges from the 
cannot thus be precisely dated. We do not agree on this point. We studied the 249 material figured by Bulot et al. (2018, excepting the specimen figured fig. 3(3)) and numerous additional representatives of $T$. royerianus from the Argiles à 251 Plicatules deposited in various French public institutions (a list of these 252 institutions is given in Bersac and Bert, 2015, p. 270).

253 Actually, the taphonomic characteristics of the whole Toxoceratoides of the Argiles à Plicatules we could study are the same as those of the sample of the $D$. 255 deshayesi Subzone's small pyrite ammonites (D. deshayesi Zone, Bersac and 256 Bert, 2015, 2018). The Toxoceratoides are thus part of this taphopopulation and 257 are assigned to the $D$. deshayesi Subzone too. Moreover, we consider that the 258 syntype of Megatyloceras ricordeanum (d'Orbigny, 1850) and the lectotype of 259 Deshayesites deshayesi (d'Orbigny, 1841) (respectively figured in Bulot et al., 260 2018, figs. 3(1) and 3(2)) are contemporaneous and assigned to the D. deshayesi 261 Subzone too (see Bersac and Bert, 2015, 2018 for explanations).

262 Concerning the taxonomic identification of the specimens figured by Bulot et al. 263 (2018), we disagree about the following determinations proposed by these 264 authors:

265 - The specimen figured under Dufrenoyia sp. in Bulot et al. (2018, fig. 3(4)) is in 266 our opinion a Deshayesites whose characters fall into the range of variability of 267 D. deshayesi (see Bersac and Bert, 2015). 
- The specimen figured under Epicheloniceras sp. (Bulot et al., 2018, fig. 3(6)) bears neither the trituberculate ribs nor the ventral depression typical of this genus. We interpret it as a robust representative of Cheloniceras cornuelianum (d'Orbigny, 1842) (see Bersac and Bert, 2018); its taphonomic characteristics are those of the $D$. deshayesi Subzone's small pyritic ammonites of the Argiles à Plicatules.

- The specimen figured under Dufrenoyia gr. dufrenoyi (Bulot et al., 2018, fig. 3(5)) is indeed a representative of the genus Dufrenoyia Kilian and Reboul, 1915 , but its black matrix clearly differs from that of the specimens of the $D$. deshayesi Subzone of the Argiles à Plicatules. This indicates that this specimen does not belong to the $D$. deshayesi Subzone of this formation but comes from a different level (for a discussion on the presence of the genus Dufrenoyia in the Argiles à Plicatules see Bersac and Bert, 2018). It is to note that this Dufrenoyia belongs to the famous Swiss paleontologist François-Jules Pictet de la Rive's (1809-1872) collection (Lionel Cavin, personnal communication) and not to the Antoine Pictet's collection ('A. Pictet' coll. in Bulot et al., 2018, caption of fig. $3(5))$

In our opinion, the specimens figured by Bulot et al. (2018, figs. 2, 3) do not contradict the fact that the topotype material of $T$. royerianus is assigned to the D. deshayesi Subzone (D. deshayesi Zone). This age is consistent with the 
288 observations Bulot et al. (2018, p. 193) made in southern France, where 'T. 289 royeri occurs in the upper part of the D. forbesi Zone' (the Bersac et al.'s (2012) 290 D. deshayesi Subzone corresponds to the upper part of the Reboulet et al.'s 291 (2014, 2018) D. forbesi Zone, Fig. 2).

293 Evolutionary characters of the Toxoceratoides of the D. deshayesi Zone in the 294 literature. Some specimens figured in the literature and assigned to the $D$. 295 deshayesi Zone have their flexus and retroversum preserved, which allows 296 comparisons with the material of the LFAB:

297 - One specimen from the Cheloniceras parinodum Subzone (=D. multicostatus 298 Subzone in Bersac et al., 2012) of southern England was figured under $T$. 299 royerianus by Casey (1960, pl. VI, figs. 2a, 2b). Its retroversum seems to exhibit 300 a mixture of royerianus and rochi ribs. Following Bulot et al. (2018, p. 190), we 301 consider this specimen as a T. royerianus.

302 - The specimen figured under T. aff. royerianus by Conte (1999, fig. 6) 303 originates from Serviers-et-Labaume (southern France) lower Aptian's Bed 2 304 ('Serviers-la-Baume', 'niveau 2' in Conte, 1999, p. 11, fig. 1). This bed seems 305 to be assigned to the $D$. grandis Subzone because it has provided Deshayesites 306 Kasansky, 1914 identified as Deshayesites grandis var. lacertosus Casey, 1964 307 and Deshayesites vectensis Spath, 1930 by Conte (1999, p. 11). The specimen of 
308 Toxoceratoides from Bed 2 bears a majority of royerianus ribs, thus we consider

309 it as a representative of $T$. royerianus.

310 - The specimens identified under Toxoceratoides subproteus Casey, 1961 by

311 Casey (1980, p. 651, pl. CIII, fig. 3) and under Tonohamites decurrens Spath,

3121924 by the same author (1960, pl. V, fig. 3; 1961a, pl. XXI, fig. 2B) originate

313 from Scaphites Beds' Bed 15 ('bed 3' in Casey, 1961b, p. 510) of Atherfield

314 Bay (Isle of Wight, southern England, see Casey et al., 1998, p. 517-519), which

315 is the last bed of the D. grandis Subzone in this section. Following Bulot et al.

316 (2018), we consider these specimens as representatives of the genus

317 Toxoceratoides and not Tonohamites Spath, 1924. Contrary to the specimens of

318 the D. grandis Subzone of the LFAB, these English specimens bear a majority

319 of rochi ribs on their stage $i i$ and we thus assign them to T. rochi. Consequently,

320 the Toxoceratoides of the D. grandis Subzone of the LFAB (Vocontian Basin)

321 bear more primitive characters (significant proportion of royerianus ribs and

322 thus low proportion of rochi ribs) than the Toxoceratoides of the upper $D$.

323 grandis Subzone of Atherfield (Anglo-Paris Basin) that bear a significant

324 proportion of rochi ribs. If one supposes that the evolution of the proportion of

325 rochi ribs is synchronous between the Vocontian Basin and the Anglo-Paris

326 Basin, the Toxoceratoides of the LFAB's Toxoceratoides Bed are slightly earlier

327 within the D. grandis Subzone than the Toxoceratoides of Scaphites Beds' Bed

32815 of Atherfield. These elements suggest that $T$. royerianus occurs at least from 
329 the $D$. deshayesi Subzone to the D. grandis Subzone (D. deshayesi Zone) and that the transition between $T$. royerianus and $T$. rochi may occur within the $D$. grandis Subzone.

- The specimen identified as Toxoceratoides royerianus from the Audouliceras renauxianum Subzone (upper D. deshayesi Zone) of the Middle Volga area 334 (Central Russia) by Baraboshkin and Mikhailova (2002, pl. VI, fig. 6) presents 335 an irregular alternation of main trituberculate and atuberculate ribs on its proversum and a flexus and retroversum bearing a mixture of possible rochi and

337 intermediate or royerianus ribs. This specimen is remarkable by the presence of 338 a spire with whorls in contact (this latter character seems to be uncommon in 339 Toxoceratoides, see Aguirre-Urreta, 1986; Avram, 2002; Frau et al., 2017; Bulot 340 et al., 2018). As far as we know, no other Helicancylidae from the $A$. 341 renauxianum Subzone of the Middle Volga area has been figured or described. 342 In our opinion, additional data on the lower Aptian Helicancylidae from this 343 area are required to identify this specimen to the species level.

345 Discussion on the identification of the Toxoceratoides from the D. multicostatus 346 and D. Grandis subzones of the LFAB. Following Frau et al. (2017) and Bulot et 347 al. (2018), the main diagnostic characters of T. royerianus ('T. royeri' in Bulot 348 et al., 2018) are (1) the predominance of stage $i i i^{\text {‘ }}$ s royerianus ribs whereas rochi 
349 ribs predominate in its daughter species $T$. rochi and (2) the lateroventral 350 tubercles of stage $i i$ that are less prominent and less flattened in T. royerianus 351 than in T. rochi.

352 The Toxoceratoides of the D. grandis Subzone of the LFAB have a stage iii 353 characterized by a mixture of royerianus and rochi ribs, with a significant 354 proportion of royerianus ribs. We thus assigned them to T. royerianus.

355 The only specimen of Toxoceratoides from the D. multicostatus Subzone of the 356 LFAB has a stage iii characterized by a mixture of royerianus and rochi ribs too.

357 Because (1) this specimen exhibits evolutionary characters of T. royerianus, 358 because (2) it is temporally located between two populations of Toxoceratoides 359 with the same evolutionary characters (earlier topotype $T$. royerianus from the 360 D. deshayesi Subzone of the Paris Basin and later T. royerianus of the $D$. 361 grandis Subzone of the LFAB) and because (3) these two latter populations are 362 both identified as $T$. royerianus, we identified this specimen as $T$. royerianus 363 too, despite its fragmentary state of preservation.

364 Biostratigraphic distribution. Deshayesites deshayesi, Deshayesites 365 multicostatus and Deshayesites grandis subzones (Deshayesites deshayesi 366 Zone). 
369 Figs. 4H-P4, 5, 7

3712011 Tonohamites sp. - Bert and Bersac, fig. 42

3722019 Toxoceratoides rochi - Bersac and Bert, p. 155, 165, figs. 5, 9, 10, 12, 15, 373 pl. 5, figs. 1-4

374 For an extensive synonymy of this species, see Frau et al. (2017).

376 Material (see Supplementary Appendix). 130 specimens from the D. furcata

377 Subzone and 3 specimens from the $D$. dufrenoyi Subzone (D. furcata Zone) 378 from GRS1, CHP and GRO sections.

380 Description of the sample of the D. furcata Subzone. Most of the 130 specimens 381 of this sample are fragmentary but they allow a good overview of the 382 ontogenetic sequence. The sample is characterized by a very important 383 morphological disparity.

384 The two subcomplete specimens of the sample are $82.7 \mathrm{~mm}$ (SBC.06061385 00001/GRS398, Fig. 4P1-P4) and 73.8 mm (SBC.06061-00001/GRS383, Fig. 
$5 \mathrm{~J})$ in total length. $\mathrm{H}$ was measured for 60 specimens, including 57 specimens

387 from GRS1 section (Supplementary Appendix). Most of the specimens are 388 deformed, which implies that the value of $\mathrm{H}$ has to be considered as an 389 estimation. This values varies by a factor of two (from 8 to $16.7 \mathrm{~mm}$ ) with an 390 average around $13 \mathrm{~mm}$. According to the fitted normal curve of its histogram, 391 the distribution of $\mathrm{H}$ seems bimodal (Fig. 6) but it does not significantly depart 392 from normality $(p=0.512)$. Specimens with small whorl height are exemplified by SBC.06061-00001/GRS206 (Fig. 5A1, A2) and SBC.06061-00001/GRS366 394 (Fig. 5G); intermediate specimens are illustrated by SBC.06061-00001/GRS287 395 (Fig. 4L) and SBC.06061-00001/GRS591 (Fig. 5I); larger ones are represented by SBC.06061-00001/GRS198 (Fig. 5Q1, Q2) and SBC.06061-00001/GRS527 397 (Fig. 5D).

The shell is planispiraled (no helical specimen was observed). The earliest 399 developments of the proversum are observable from a whorl height of $0.8 \mathrm{~mm}$ 400 (Fig. 7I, J, L) and they never exhibit any spiral. The proversum is more or less 401 curved. The angle between the proversum and retroversum is variable from a 402 specimen to another: SBC.06061-00001/GRS580 (Fig. 5O1) and SBC.06061403 00001/GRS221 (Fig. 5H1) have a rather narrow angle, whereas SBC.06061404 00001/GRS284 (Fig. 4H) and SBC.06061-00001/GRS383 (Fig. 5J) have an 405 open angle. The retroversum seems to reach a significant length in some 406 specimens (Fig. 7G). 
407 The ornamentation and duration of the ontogenetic stages vary significantly 408 from a specimen to another:

409 - Stage $i$ is composed of dense and thin ribs that can be atuberculate or bear a 410 discrete lateroventral tubercle. These ribs do not attenuate when crossing the 411 siphonal area. This stage is generally present in the earliest part of the 412 proversum (Fig. 7I, L), but its duration strongly varies from a specimen to 413 another: it can be very short (Fig. 4J1-J4), intermediate (Fig. 4P1-P4, Fig. 5C) 414 or more rarely can be present on nearly the entire proversum. In this last case, 415 the specimens have a very slender shape (Fig. 7G, H).

416 - Stage $i i$ is represented by tuberculate main ribs and atuberculate intercalary 417 ribs. The ribs are generally simple, straight, rectiradiate or prorsiradiate and 418 attenuated on the siphonal area (Fig. 4M). The main ribs first bear a lateral and a 419 lateroventral tubercle (stage iia). They are rarely separated by one or more 420 atuberculate intercalary ribs. Thereafter, a laterodorsal tubercle arises on the 421 main ribs and the intercalary ribs become more frequent (stage iib, Fig. 4N1422 N3). Rarely, the main ribs can be looped (Fig. 5Q1) or the intercalary ribs may 423 be absent (Fig. 5C, D). Alternation between main and intercalary ribs is 424 generally regular (Fig. 4K, O1-O3), but it can be irregular in some cases. In both 425 stages iia and $i i b$, the lateroventral tubercles are larger than the other tubercles. 426 They are conical or claviform but their shape is altered by post mortem 
427 deformation. Transition between stages iia and iib is very variable from a 428 specimen to another. Stage $i i$ ends between the beginning (Fig. 5O1) and the end 429 of the flexus (Fig. 5F1, F2).

430 - Stage iii is in most of the cases composed of simple, dense, straight, flattened 431 or sharp uniform ribs (rochi ribs, Fig. 7A, B1). They can be attenuated (Fig. 5E) 432 or not (Fig. $5 \mathrm{~K} 1, \mathrm{~K} 2$ ) on the ventral area. They rarely bear a lateroventral 433 tubercle (generally discrete, Fig. 5E), or lateral and lateroventral tubercles (Fig. $4345 \mathrm{~F} 1, \mathrm{~F} 2)$. Some specimens exhibit rare royerianus ribs (Fig. 7C).

435 The dorsal area of the proversum, the flexus and the retroversum bear thin and 436 dense ribs, concave toward the peristome (Fig. 4J2, N3, O3). No specimen has 437 its peristome preserved. Septa can be observed on several specimens but the 438 suture line is too poorly preserved to be studied. The phragmocone can occupy 439 the whole proversum and the beginning of the flexus (Figs. 4P2, 5H1, O1, 7A, 440 F). On several specimens, the last septum is located in the proversum (Figs. 4J1, $441 \mathrm{~L}, \mathrm{~N} 1,5 \mathrm{~L})$.

442 The proportion of rochi ribs was calculated for 52 specimens, including 51 443 specimens from GRS1 section. In this last section, the mean proportion of rochi 444 ribs varies from $91.59 \%$ to $96.17 \%$ from Bed 99 to Bed 106, with a total mean 445 value of $94.52 \%$ (Table 1). The histogram of rochi ribs proportion shows a 
446 continuous, unimodal and strongly negatively skewed distribution (Fig. 8). It

447 significantly departs from normality $(p=0)$.

449 Description of the sample of the D. dufrenoyi Subzone. Only 3 specimens were 450 collected in the D. dufrenoyi Subzone. SBC06061/00001/GRS586 (GRS1, Bed 451 110), figured in Bert and Bersac (2011, fig. 42) and SBC06061/00001/GRS728 452 (GRS1, Bed 113) are fragments of proversum adorned with dense, straight, 453 uniform and prorsiradiate ribs bearing a discrete lateroventral tubercle (stage $i$ ). 454 SBC06061/00001/GRS731 (GRS1, Bed 113 figured Fig. 7O) is a very poorly 455 preserved fragment of proversum, flexus and retroversum. The proversum bears 456 trituberculate ribs separated by one or two intercalaries. The ornamentation on 457 the flexus and retroversum cannot be studied and the proportion of rochi ribs 458 cannot be calculated.

460 Variability and homogeneity of the Toxoceratoides of the $\mathrm{D}$. furcata Zone of the 461 LFAB. As far as possible, ammonite populations have to be studied from a 462 restricted stratigraphic interval in order to avoid time-averaging (see discussion 463 in de Baets et al., 2015, p. 363). This is the case of our sample, which is 464 restricted to the $D$. furcata Subzone, excepting 3 poorly preserved specimens 
465 from the D. dufrenoyi Subzone. The following interpretations are thus based on 466 the sample of the D. furcata Subzone only.

467 This sample has a very important morphological disparity. This variability is 468 continuous and similar in every beds (Fig. 9). In GRS1 section, which provides 469 most of the specimens of the D. furcata Subzone, changes from a bed to another 470 are limited to a slight increase of $\mathrm{H}$ and a slight increase of the proportion of 471 rochi ribs (Table 1). The value of $\mathrm{H}$ allows estimating adult size in tripartite 472 ammonites (see discussion in Bersac and Bert 2020). Consequently, we consider 473 a progressive increasing adult size of the Toxoceratoides through the D. furcata 474 Subzone of the LFAB.

475 We interpret the morphological disparity of the sample of the D. furcata Zone as 476 being driven by several processes (Fig. 9):

477 - The variation in duration of the ontogenetic stages: this corresponds to a 478 process of heterochronic type that plays a significant role in ammonoid 479 intraspecific variability in general (De Baets et al., 2015; Vennari and Aguirre480 Urreta, 2019);

481 - The variation of the ornamentation of each ontogenetic stage: within each 482 stage, there is a variation in rib density and in the number of intercalary ribs. 483 This kind of 'multipolar' variability is extensively documented among 484 ammonoids (Bert, 2013, De Baets et al., 2015). In stage iii, this variability 
485 concerns in addition the proportion of rochi ribs. This proportion continuously 486 varies from a specimen to another (Fig. 8). Its strongly negatively skewed 487 distribution (which thus significantly departs from normality) can be due to the 488 fact that the proportion of rochi ribs in this sample tends toward the value of $489100 \%$, without, naturally, exceeding it.

490 - The delayed disappearance of a character through ontogeny: it could explain 491 the presence of ribs with lateroventral and/or lateral tubercles (characteristic of 492 the main ribs of stage ii) in some specimens' stage iii. Such phenomenon was 493 described in the lower Aptian ammonite genus Cheloniceras Hyatt, 1903 494 (Bersac and Bert, 2018);

$495-\mathrm{H}$ varies in a continuous way by a factor 2 and its distribution does not 496 significantly depart from normality (Fig. 6), which suggests a variation of the 497 adult size in the same way. Such significant variation has already been 498 documented among heteromorph tripartite ammonites (Landman, 1987; see 499 discussion in Bersac and Bert, 2020);

500 - The variation of coiling (more or less curved proversum, variable angle 501 between proversum and retroversum). This kind of variability among 502 heteromorph ammonites has already been described (Kakabadze, 2004; Bert, 503 2013; Delanoy et al., 2013; Bersac and Bert, 2020), especially in other 504 representatives of the family Helicancylidae (Helicancylus bonarellii (Leanza, 
505 1970) in Aguirre-Urreta, 1986, p. 292, fig. 13A-F; Toxoceratoides nagerai 506 (Leanza, 1970) in Aguirre-Urreta, 1986, p. 298, fig. 16A-D, 17A-D).

507 The variability of the sample of the D. furcata Subzone appears to be continuous 508 and involves processes already observed in other ammonite monospecific 509 samples. Consequently, we interpret this sample as being monospecific. Such 510 continuous variability is not involved by sexual dimorphism (see Bert, 2013, 5112019 for a description of the various rules of ammonoid intraspecific 512 variability).

513 Although they are fragmentary, we have no argument to taxonomically isolate 514 the three specimens of the $D$. dufrenoyi Subzone from the rest of the sample.

516 Taxonomic attribution and consequences. The sample of Toxoceratoides of the

517 D. furcata Zone of the LFAB is characterized by the predominance of rochi ribs 518 in its stage $i i i$; its biostratigraphic position is also similar to that of $T$. rochi in its 519 type locality (Frau et al., 2017, p. 340). For these reasons, we assigned this 520 sample to T. rochi.

521 This interpretation implies that the disparity of $T$. rochi encompasses

522 morphologies corresponding to several species of Toxoceratoides, but also 523 morphologies that are atypical among Toxoceratoides and which are often 
524 assigned to other genera of Helicancylidae. Therefore, slender specimens with 525 long stage $i$ (i.e. with feebly tuberculate proversum, Fig. 7G) resemble the genus 526 Tonohamites. Among the Helicancylidae, co-occurrence of specimens with 527 feebly tuberculate proversum and specimens with tuberculate proversum was 528 already observed in the D. grandis Subzone of southern England by Casey 529 (1960, 1961a). This author assigned the feebly tuberculate specimens to the 530 genus Tonohamites and the tuberculate specimens to the genera Tonohamites 531 and Toxoceratoides. Specimens with a stage $i i$ essentially composed of main ribs 532 (i.e. without intercalaries, Fig. 5D) mimic representatives of the genus 533 Helicancylus Gabb, 1869 or the species Toxoceratoides krenkeli Förster, 1975 534 (Förster, 1975; Aguirre-Urreta, 1986). Fragments with such ornamentation from 535 the $C$. parinodum Subzone (=D. multicostatus Subzone of Bersac et al., 2012) 536 and the D. grandis Subzone of southern England were described under 537 Toxoceratoides cf. fustiformis (von Koenen, 1902) by Casey (1961a, p. 83, pl. 538 XVII, fig. 4). Large sized robust specimens resemble Toxoceratoides stefanescui 539 Avram, 2002 (Avram, 2002, this species is regarded as a junior synonym of $T$. 540 rochi by Frau et al., 2017). Specimens with slender stage $i i$ (main ribs separated 541 by several intercalaries, Figs. 5H, 7A) are similar to Toxoceratoides transitorius 542 Avram, 2002. Small fragments of proversum bearing a stage $i$ look like 543 Toxoceratoides emericianum (d'Orbigny, 1842), etc. 
544 Biostratigraphic distribution. Dufrenoyia furcata and Dufrenoyia dufrenoyi

545 subzones (Dufrenoyia furcata Zone) and probably upper part of Deshayesites

546 grandis Subzone (Deshayesites deshayesi Zone) of southern England.

548 3.2. Evolutionary patterns of the Toxoceratoides of the LFAB (Fig. 10)

550 The interpretations proposed in this chapter are based on data from the LFAB

551 only. The proportion of rochi ribs in the D. furcata Zone could have been

552 quantified in several beds only in GRS1 section (Table 1): we thus have studied

553 the evolution of this character only in this section.

555 3.2.1. From the D. forbesi Zone to the D. grandis Subzone

557 In this interval, the Toxoceratoides:

558 - belong to the species $T$. royerianus;

559 - have a small population. In the D. forbesi Zone and the D. multicostatus 560 Subzone, the population size of Toxoceratoides could have been small, as 561 suggested by the very small number of specimens collected (2 specimens, see 
562 Supplementary Appendix). In the D. grandis Subzone, the population size 563 slightly increases (Bersac and Bert, 2019, fig. 18);

564 - have a low proportion of rochi ribs that may slowly increase over time (Table $5651)$;

566 - have a globally robust shape in the D. grandis Subzone (stage $i i$ with strong 567 tuberculate ribs separated by one atuberculate rib and stage iii bearing bifid and 568 monotuberculate royerianus ribs). Note that in the earlier levels of the LFAB, 569 the specimens are too fragmentary to determine their robustness.

571 3.2.2. From the $D$. grandis Subzone to the $D$. furcata Zone

573 - The population size of Toxoceratoides sharply increases (Bersac and Bert, 574 2019, fig. 18).

575 - The proportion of rochi ribs sharply increases at the same time, rising from 576 about $50 \%$ to $92 \%$ (Table 1 ).

577 - The specimens are more slender on average, due to a significant intraspecific 578 variability. 
579 These abrupt evolutionary changes compared to the precedent interval represent 580 a speciation event that determines the transition from $T$. royerianus to $T$. rochi. 581 This event could occur during the late D. grandis Subzone (see Chapter 3.1, 582 'discussion' of the systematic palaeontology of T. royerianus).

583 It is to note that we could not highlight in the LFAB the evolution of the 584 lateroventral tubercles of stage $i i$ described by Bulot et al. (2018), due to post 585 mortem deformation of the specimens.

587 3.2.3. During the D. furcata Zone

589 - The proportion of rochi ribs continues to increase, but slower than before (from 590 about $92 \%$ to $96 \%$, see Table 1$)$.

591 - The adult size of the specimens seems to slowly increase (see $\mathrm{H}$ in Table 1). 
595 T. sp., T. royerianus and T. rochi have been recognized within our sample of 596 Toxoceratoides from the $D$. forbesi Zone - D. furcata Zone interval of the 597 LFAB.

598 The large size of our sample of Toxoceratoides rochi (133 specimens) allowed 599 highlighting the unprecedented range of morphological disparity of this species. 600 This disparity is so significant that it encompasses the morphology of several 601 species of Toxoceratoides and even of some genera of Helicancylidae 602 (Tonohamites, Helicancylus). Nevertheless, additional data are necessary to 603 decide if some of these taxa can be synonymized or not with $T$. rochi and 604 Toxoceratoides respectively. If we had applied a typological concept of the 605 species to the sample studied, we would probably have recognized dozens of 606 species and several genera of Helicancylidae.

607 Concerning the evolutionary patterns, the proportion of rochi ribs seems to be 608 characterized by periods of slow increase separated by a sudden significant 609 increase between the D. grandis Subzone and the D. furcata Subzone. This 610 sudden increase, that occurs in a transgressive context (Bersac and Bert, 2019), 611 is contemporaneous with the sharp increase ('bloom') of the population size of 612 Toxoceratoides, which constitutes a speciation event determining the transition 613 from $T$. royerianus to $T$. rochi. These elements suggest that the evolution of 
614 Toxoceratoides could correspond to a punctuated equilibrium model (Eldredge 615 and Gould, 1972) rather than a gradualist model.

616 The increasing trend in $\mathrm{H}$ highlighted in our samples is based on the study of 617 frequently deformed specimens. As a consequence, this trend has to be 618 confirmed by studying contemporaneous populations of non-deformed 619 Toxoceratoides from other paleogeographic areas.

620 The proportion of rochi ribs in Toxoceratoides may be used as a complementary 621 biostratigraphic tool. However, it would be necessary to study this parameter in 622 larger samples from the $D$. grandis Subzone and from earlier biostratigraphic 623 units to confirm this proposition. It would also be interesting to determine if this 624 parameter could be modulated or not by paleogeography.

626 Disclosure of interest

628 The authors declare that they have no competing interest. 
632 We warmly thank the Editor-in-Chief, the Associate Editor, Yves Dutour (Aix633 en-Provence, France) and an anonymous reviewer. Their carefull reviewing and 634 their relevant and valuable comments greatly helped to improve the manuscript.

636 References

638 Aguirre-Urreta, M. B., 1986. Aptian ammonites from the Argentinian Austral 639 Basin, the subfamily Helicancylinae, Hyatt, 1894. Annals of the South African 640 Museum 96 (7), 271-314.

642 Amédro, F., Matrion, B., 2004. Les ammonites aptiennes des Argiles à 643 Plicatules de la bordure orientale du bassin de Paris: un aperçu. Bulletin de 644 l'Association Géologique Auboise 24-25, 75-80.

645

646 Avram, E., 2002. Representatives in Romania of the genera Dissimilites Sarkar, 6471954 and Toxoceratoides Spath, 1924 (Ancyloceratina, Ammonoidea). Acta 648 Palaeontologica Romaniae 3 (2001), 23-30. 
650 Baraboshkin, E.Y., Mikhailova, I.A., 2002. New stratigraphical scheme of the 651 Lower Aptian of Middle Volga area. Stratigraphy and Geological Correlation 65210 ,

$653 \quad 82-105$.

655 Bersac, S., Bert, D., Matrion, B, 2012. Revision of the index-species 656 Deshayesites deshayesi (Ammonoidea, lower Aptian, Lower Cretaceous):

657 Taxonomic and biostratigraphic consequences. In: Bersac, S. and Bert, D. 658 (Eds.), First meeting of the Research Group for Paleobiology and 659 Biostratigraphy of the Ammonites. Boletin del Instituto de Fisiografia y 660 Geologia 82, 31-33.

661

662 Bersac, S., Bert, D., 2015. Two ammonite species under the same name: 663 revision of Deshayesites deshayesi (d'Orbigny, 1841) based on topotype 664 material (lower Aptian, Lower Cretaceous, Northeast of France). Annales de 665 Paléontologie 101(4), 265-294. 
667 Bersac, S., Bert, D., 2018. Revision of the lower Aptian (Lower Cretaceous) 668 ammonite species Cheloniceras cornuelianum (d'Orbigny, 1841). Annales de 669 Paléontologie 104(1), 45-70.

670

671 Bersac, S., Bert, D., 2019. The lower Aptian ammonites of the Les Ferres Aptian 672 Basin (Lower Cretaceous, Southeast of France). Part I: Introduction and 673 biostratigraphy. Carnets de Géologie (Notebooks on Geology) 19(9), 149-183.

675 Bersac, S., Bert, D., 2020. The heteromorph ammonite genus Ancyloceras 676 (Ancyloceratidae) in the Paris Basin (lower Aptian, Lower Cretaceous, 677 Northeast of France). Annales de Paléontologie 106

678 https://doi.org/10.1016/j.annpal.2019.102365.

680 Bert, D., 2009. Description de Artareites landii nov. (Ammonoidea) du 681 Barrémien supérieur de Majastre (Sud-Est de la France) et discussion sur les 682 Helicancylidae Hyatt, 1894. Annales de Paléontologie 95 (3), 139-163. 
684 Bert, D., 2013. Factors of intraspecific variability in ammonites, the example of 685 Gassendiceras alpinum (d'Orbigny, 1850) (Hemihoplitidae, Upper Barremian). 686 Annales de Paléontologie 100 (3), 217-236.

688 Bert, D., 2019. Les lois de la variabilité intraspécifique chez les 689 ammonites. Congrès de l'Association Paléontologique Française (APF), April 690 2019, Aix-en-Provence, France.

691

692 Bert, D., Bersac, S., 2011. Buts et méthodes du "levé de coupe". Fossiles 6, 4969361.

695 Bulot, L.G., 2010. Appendix. Systematic paleontology of Aptian and Albian 696 ammonites from southwest Iran. In: Vincent, B., van Buchem, F.S.P., Bulot, 697 L.G., Immenhauser, A., Caron, M., Baghbani, D., Huc, A.Y. (Eds.), Carbon698 isotope stratigraphy, biostratigraphy and organic matter distribution in the 699 Aptian-Lower Albian successions of southwest Iran (Dariyan and Kazhdumi 700 formations). GeoArabia Special Publication 4, 167-197. 
702 Bulot, L. G., Frau, C., Pictet, A., 2018. Revision of Toxoceratoides 703 royeri (d'Orbigny, 1842) and its bearing on the systematics of the Aptian 704 Acrioceratidae Vermeulen, 2004 (Ammonoidea, Ancyloceratina, 705 Ancyloceratoidea). Cretaceous Research 88, 187-196.

707 Casey, R., 1960. A monograph of the Ammonoidea of the Lower Greensand, 708 part I. Palaeontographical Society (1959), i-xxxxvi + 1-44.

710 Casey, R., 1961a. A monograph of the Ammonoidea of the Lower Greensand, 711 part II. Palaeontographical Society (1960), 41-118.

713 Casey, R., 1961b, The stratigraphical palaeontology of the Lower Greensand. 714 Palaeontology, London. Volume 3, 487-621.

716 Casey, R, 1980. A monograph of the Ammonoidea of the Lower Greensand, part 717 IX. Palaeontographical Society, London, 633-660.

719 Casey, R., Bayliss, H.M., Simpson, M.I., 1998. Observations on the 720 lithostratigraphy and ammonite succession of the Aptian (Lower Cretaceous) 
721 Lower Greensand of Chale Bay, Isle of Wight, UK. Cretaceous Research 19, $722 \quad 511-535$.

724 Conte, G., 1999. Éléments de la faune de l'Aptien inférieur (Bédoulien) de 725 Serviers-La-Baume (Gard). Bulletin de la Société d'Etude des Sciences 726 Naturelles de Nîmes et du Gard 62, 11-15.

728 Corroy, G., 1925. Le Néocomien de la bordure orientale du Bassin de Paris. 729 Imprimerie J. Coubé and Fils, Nancy.

731 De Baets, K., Bert, D., Hoffmann, R., Monnet, C., Yacobucci, M.M., Klug, C., 732 2015. Ammonoid intraspecific variability. In: Klug, C., Korn, D., De Baets, K., 733 Kruta,I., Mapes, R.H. (Eds.), Ammonoid paleobiology: from anatomy to 734 ecology. Topics in Geobiology 43, 359-426.

736 Delanoy, G., Baudouin, C., Gonnet, R., Bert, D., 2008. Sur les faunes 737 d'ammonites (Crétacé inférieur) du niveau glauconieux de la carrière des Trois738 Vernes, près de Crest (Drôme, Sud-est de la France). Annales du Muséum 739 d'Histoire Naturelle de Nice XXIII, 11-65. 
741 Delanoy, G., Moreno-Bedmar, J. A., Ruiz, J. J., Tolós Llàdser, D., 2013.

742 Xerticeras gen. nov., a new genus of micromorphic heteromorph ammonite 743 (Ancyloceratina, Ancyloceratidae) from the lower Aptian of Spain. Carnets de 744 Géologie [Notebooks on Geology], Brest, Article 2013/02 (CG2013_A02), 89745103.

746

747 Eldredge, N., Gould, S.J., 1972. Punctuated equilibria: An alternative to phyletic 748 gradualism. In: Schopf, T. J. M. (Ed.), Models in Paleobiology. Freeman749 Cooper \& Co., San Francisco, 82-115.

751 Förster, R., 1975. Die geologische Entwicklung von Süd-Mozambique seit der 752 Unterkreide und die Ammoniten-Fauna von Unterkreide und Cenoman. 753 Geologisches Jahrbuch (B) 12, 3-324.

755 Frau, C., Bulot, L.G., Delanoy, G., 2017. New and poorly known Aptian 756 Acrioceratidae (Ancyloceratoidea, Ammonoidea) from Cassis - Roquefort-la757 Bédoule (Bouches-du-Rhône). Neues Jahrbuch für Geologie und Paläontologie 758 Abhandlungen 238 (3), 335-346. 
760 Hammer, O., Harper, D.A.T., 2006. Paleontological data analysis. Blackwell 761 publishing, Oxford.

763 Hammer, O., Harper, D.A.T., Ryan, P.D., 2001. PAST: Paleontological 764 Statistics Software Package for Education and Data Analysis. Palaeontologia 765 Electronica 4 (1), 9 p.

767 Kakabadze M. V., 2004. Intraspecific and intrageneric variabilities and their 768 implication for the systematics of Cretaceous heteromorph ammonites; a review. 769 Scripta Geologica 128, 17-37.

771 Kakabadze, M. V., Hoedemaeker, P. J., 2004. Heteromorphic ammonites from 772 the Barremian and Aptian strata of Colombia. Scripta Geologica 128, 39-182.

774 Klein, J., Busnardo, R., Company, M., Delanoy, G., Kakabadze, M., Reboulet, 775 S., Ropolo, P., Vašíček, Z., Vermeulen, J., 2007. Fossilium Catalogus I: 776 Animalia. Pars 144. Lower Cretaceous Ammonites III. Bochianitoidea, 777 Protancyloceratoidea, Ancyloceratoidea, Ptychoceratoidea. Backhuys 778 Publishers, Leiden. 
Landman, N.H., 1987. Ontogeny of Upper Cretaceous (Turonian-Santonian)

781

782

783

784

785

786

787

788

789

790

791

792

793 794

798 Reboulet, S., Szives, O., Aguirre-Urreta, B., Barragan, R., Company, M., Frau,

scaphitid ammonites from the Western Interior of North America: systematics, developmental patterns, and life history. Bulletin of the American Museum of Natural History 185 (2), 117-241.

Mikhailova, I.A., Baraboshkin, E.J., 2002. Volgoceratoides and Koeneniceras new small-size Lower Aptian heteromorphs from the Ulijanovsk Region (Russian Platform). Abhandlungen der Geologischen Bundesanstalt 57, 539553.

Reboulet, S., Szives, O., Aguirre-Urreta, B., Barragan, R., Company, M., Idakieva, V., Ivanov, M., Kakabadze, M.V., Moreno-Bedmar, J.A., Sandoval, J., Baraboshkin, E.J., Caglar, M.K., Fozy, I., Gonzàlez-Arreola, C., Kenjo, S., Lukeneder, A., Raisossadat, S.N., Rawson, P.F., Tavera, J.M., 2014. Report on the 5th International Meeting of the IUGS Lower Cretaceous Ammonite Working Group, the "Kilian Group" (Ankara, Turkey, 31st August 2013). Cretaceous Research 50, 126-137. 
800 Ploch, I., Raisossadat, S.N., Vašíček, Z., Baraboshkin, E.J., Mitta, V.V., 2018.

801 Report on the $6^{\text {th }}$ International Meeting of the IUGS Lower Cretaceous 802 Ammonite Working Group, the "Kilian Group" (Vienna, Austria, $20^{\text {th }}$ August 803 2017). Cretaceous Research 91, 100-110.

804

805 Vennari, V.V., Aguirre-Urreta, M.B., 2019. Intraspecific variability, 806 biostratigraphy and paleobiological significance of the Southern Gondwana 807 ammonoid genus Lytohoplites Spath. Journal of Paleontology 93 (4), 702-726.

808

809 Vermeulen, J., 2004. Vers une nouvelle classification à fondement 810 phylogénétique des ammonites hétéromorphes du Crétacé inférieur 811 méditerranéen. Le cas des Crioceratitidae Gill, 1871, nom. correct., 1952, des 812 Emericiceratidae fam. nov. et des Acrioceratidae fam. nov. (Ancylocerataceae 813 Gill, 1871). Riviéra Scientifique, 88, 69-92.

815 Figures, table and plates

817 Fig. 1. Map of the Les Ferres area with location of the sections that provided the 818 studied material. Geographic coordinates of the sections: GRS1 (lat.: $81943.842177^{\circ}$, long.: $7.076508^{\circ}$ ), VAL (lat.: $43.842256^{\circ}$, long.: $7.09677^{\circ}$ ), GRO 
(lat: $43.843379^{\circ}$, long: $7.1^{\circ}$ ), CHP (lat.: $43.845193^{\circ}$, long.: $7.102648^{\circ}$ ), CLE (lat.: $43.845193^{\circ}$, long.: $7.102648^{\circ}$ ). See online version for colours.

Fig. 2. Bio-chronostratigraphic charts used in the present work. SZS: Standard Mediterranean Zonal Scheme. St.: stages.

Fig. 3. Toxoceratoides shell morphological terminology and measured 827 parameter. H: whorl height at the middle of the flexus.

829 Fig. 4. The arrow indicates the beginning of the body chamber. All specimens: Bersac's collection. A: Toxoceratoides sp., SBC.06061-00007/CLE036, CLE 831 section, Bed 400, Deshayesites forbesi Zone. B: Toxoceratoides royerianus 832 (d'Orbigny, 1842), SBC.06061-00003/VAL066, VAL section, Bed 405, 833 Deshayesites multicostatus Subzone (Deshayesites deshayesi Zone). C-G: 834 Toxoceratoides royerianus (d'Orbigny, 1842), Deshayesites grandis Subzone 835 (Deshayesites deshayesi Zone). C: SBC.06061-00006/CHP359, CHP section, 836 Bed 416. D: SBC.06061-00006/CHP041, CHP section, Bed 416. E: SBC.06061837 00006/CHP038, CHP section, Bed 416. F: SBC.06061-00007/CLE004, CLE 838 section, Bed 416. G: SBC.06061-00001/GRS510, GRS1 section, Bed 97. H-P: 
Toxoceratoides rochi Casey, 1961, Dufrenoyia furcata Subzone (Dufrenoyia furcata Zone). H: SBC.06061-00001/GRS284, GRS1 section, Bed 102. I:

841 SBC.06061-00001/GRS222, GRS1 section, Bed 102. J: SBC.06061842 00001/GRS358, GRS1 section, Bed 100. K: SBC.06061-00005/GRO076, GRO

843 844 845 846 847 section, Bed 418. L: SBC.06061-00001/GRS287, GRS1 section, Bed 102. M: SBC.06061-00001/GRS159, GRS1 section, Bed 100. N: SBC.0606100001/GRS414, GRS1 section, Bed 104. O: SBC.06061-00001/GRS186, GRS1 section, Bed 100. P: SBC.06061-00001/GRS398, GRS1 section, Bed 104.

Fig. 5: Toxoceratoides rochi Casey, 1961, GRS1 section, Dufrenoyia furcata Subzone (Dufrenoyia furcata Zone), Bersac's collection. The arrow indicates the beginning of the body chamber. A: SBC.06061-00001/GRS206, Bed 102. B:

SBC.06061-00001/GRS238, Bed 102. C: SBC.06061-00001/GRS585, Bed 102. D: SBC.06061-00001/GRS527, Bed 104. E: SBC.06061-00001/GRS607, Bed 102. F: SBC.06061-00001/GRS367, Bed 99. G: SBC.06061-00001/GRS366, Bed 99. H: SBC.06061-00001/GRS221, Bed 102. I: SBC.0606100001/GRS591, Bed 102. J: SBC.06061-00001/GRS383, Bed 102. K: SBC.06061-00001/GRS579, Bed 102. L: SBC.06061-00001/GRS524, Bed 104. 7 M: SBC.06061-00001/GRS289, Bed 102. N: SBC.06061-00001/GRS321, Bed 
99. O: SBC.06061-00001/GRS580, Bed 102. P: SBC.06061-00001/GRS034, Bed 102. Q: SBC.06061-00001/GRS198, Bed 100.

Fig 6. Histogram of $\mathrm{H}$ (whorl height at the middle of the flexus in $\mathrm{mm}$ ) of 57 specimens of Toxoceratoides rochi Casey, 1961 from the Dufrenoyia furcata Subzone (Dufrenoyia furcata Zone, lower Aptian) of the Les Ferres Aptian Basin and result of the Shapiro-Wilk normality test. Black curve: fitted normal curve. Dark red curve: kernel density estimator. See online version for colours.

Fig. 7. The arrow indicates the beginning of the body chamber. All specimens: Bersac's collection. A-N: Toxoceratoides rochi Casey, 1961, Dufrenoyia furcata Subzone (Dufrenoyia furcata Zone). A: SBC.06061-00001/GRS224, GRS1 section, Bed 102. B: SBC.06061-00001/GRS644, GRS1 section, Bed 102. C: SBC.06061-00001/GRS649, GRS1 section, Bed 106. D: SBC.0606100001/GRS582, GRS1 section, Bed 102. E: SBC.06061-00006/CHP201, CHP section, Bed 421. F: SBC.06061-00001/GRS022, GRS1 section, Bed 102. G: SBC.06061-00001/GRS616, GRS1 section, Bed 99. H: SBC.0606100001/GRS323, GRS1 section, Bed 99. I: SBC.06061-00001/GRS182, GRS1 section, Bed 100. J: SBC.06061-00001/GRS046, GRS1 section, Bed 102. K: SBC.06061-00001/GRS522, GRS1 section, Bed 104. L: SBC.06061- 
section, Bed 104. N: SBC.06061-00001/GRS127, GRS1 section, Bed 102. O:

Toxoceratoides rochi Casey, 1961, SBC.06061-00001/GRS731, GRS1 section,

Bed 113. Dufrenoyia dufrenoyi Subzone (Dufrenoyia furcata Zone).

Fig 8. Histogram of rochi ribs proportion of 52 specimens of Toxoceratoides rochi Casey, 1961 from the Dufrenoyia furcata Subzone (Dufrenoyia furcata Zone, lower Aptian) of the Les Ferres Aptian Basin section and result of the Shapiro-Wilk normality test.. Black curve: fitted normal curve. Dark red curve: kernel density estimator. See online version for colours.

Fig. 9. Patterns of intraspecific variability of Toxoceratoides rochi Casey, 1961. A: slightly curved proversum, intermediate angle between proversum and retroversum. B: substraight proversum, open angle. C: substraight proversum, narrow angle. D: stage $i i$ with rare intercalary ribs, stage $i i i$ with rare royerianus ribs. E: stage $i i$ with one intercalary rib between main ones on a regular basis, stage $i i i$ with only rochi ribs. F: stage $i i$ with several intercalated ribs between primary ones, stage $i i i$ with rare royerianus ribs. G: early onset of stage $i i$, late onset of stage iii. H: later onset of stage ii, early onset of stage iii. I: very late ending of stage $i$, no stage $i i$. J: large size. K: intermediate size. L: small size. 
899 Fig. 10. Evolutionary patterns of the genus Toxoceratoides Spath, 1924 900 according to Bulot et al. (2018) and this work. Biostratigraphic chart: see Fig. 2.

\begin{tabular}{|c|c|c|c|c|}
\hline & & & $\begin{array}{l}\text { Proportion of } \\
\text { rochi ribs }\end{array}$ & $\mathrm{H}(\mathrm{mm})$ \\
\hline \multirow{5}{*}{$\begin{array}{c}\text { Toxoceratoides } \\
\text { rochi }\end{array}$} & \multirow{5}{*}{$\begin{array}{c}\text { GRS } 1 \text { section } \\
\text { (les Graous } \\
\text { Member, } \\
\text { Dufrenoyia } \\
\text { furcata Subzone) }\end{array}$} & Bed 106 & $94.11 \%(\mathrm{~N}=1)$ & $18.8(\mathrm{~N}=1)$ \\
\hline & & Bed 104 & $94.7 \%(\mathrm{~N}=5)$ & $13.88(\mathrm{~N}=5)$ \\
\hline & & Bed 102 & $96.17 \%(\mathrm{~N}=28)$ & $13.47(\mathrm{~N}=32)$ \\
\hline & & Bed 100 & $91.91 \%(\mathrm{~N}=9)$ & $12.95(\mathrm{~N}=10)$ \\
\hline & & Bed 99 & $91.59 \%(\mathrm{~N}=8)$ & $11.97(\mathrm{~N}=9)$ \\
\hline \multirow{2}{*}{$\begin{array}{c}\text { Toxoceratoides } \\
\text { royerianus }\end{array}$} & \multicolumn{2}{|c|}{$\begin{array}{l}\text { Toxoceratoides Bed } \\
\text { (Deshayesites grandis } \\
\text { Subzone) }\end{array}$} & $47.88 \%(\mathrm{~N}=4)$ & $10.04(\mathrm{~N}=5)$ \\
\hline & \multicolumn{2}{|c|}{$\begin{array}{c}\text { Ammonitoceras Level? } \\
\text { (Deshayesites multicostatus } \\
\text { Subzone) }\end{array}$} & $42.85 \%(\mathrm{~N}=1)$ & $13.9(\mathrm{~N}=1)$ \\
\hline $\begin{array}{c}\text { Toxoceratoides } \\
\text { sp. }\end{array}$ & \multicolumn{2}{|c|}{$\begin{array}{c}\text { Top of HAL } \\
\text { (Deshayesites forbesi Zone) }\end{array}$} & $0 \%(\mathrm{~N}=1)$ & $9(\mathrm{~N}=1)$ \\
\hline
\end{tabular}


903 Table 1. Mean values of the proportion of rochi ribs and whorl height at the 904 middle of the flexus $(\mathrm{H})$ of the taxa recognized in the present article. $\mathrm{N}=$ 905 number of studied specimens. HAL $=$ Hauterivian-Aptian limestones. Litho- and 906 biostratigraphic charts after Bersac and Bert (2019) and Fig. 2. 


\section{Declaration of interests}

The authors declare that they have no known competing financial interests or personal relationships that could have appeared to influence the work reported in this paper.

$05^{\text {th }}$ October 2020

Stéphane Bersac

Didier Bert 